University of Nebraska - Lincoln

DigitalCommons@University of Nebraska - Lincoln

Agronomy \& Horticulture -- Faculty Publications

Agronomy and Horticulture Department

2007

\title{
The Ripple Effect: Biofuels, Food Security, and the Environment
}

\author{
Rosamond L. Naylor \\ Stanford University \\ Adam Liska \\ University of Nebraska-Lincoln, aliska2@unl.edu \\ Marshall B. Burke \\ Stanford University \\ Walter P. Falcon \\ Stanford University \\ Joanne C. Gaskell \\ Stanford University
}

See next page for additional authors

Follow this and additional works at: https://digitalcommons.unl.edu/agronomyfacpub

Part of the Plant Sciences Commons

Naylor, Rosamond L.; Liska, Adam; Burke, Marshall B.; Falcon, Walter P.; Gaskell, Joanne C.; Rozelle, Scott D.; and Cassman, Kenneth G., "The Ripple Effect: Biofuels, Food Security, and the Environment" (2007). Agronomy \& Horticulture -- Faculty Publications. 386.

https://digitalcommons.unl.edu/agronomyfacpub/386

This Article is brought to you for free and open access by the Agronomy and Horticulture Department at DigitalCommons@University of Nebraska - Lincoln. It has been accepted for inclusion in Agronomy \& Horticulture -Faculty Publications by an authorized administrator of DigitalCommons@University of Nebraska - Lincoln. 


\section{Authors}

Rosamond L. Naylor, Adam Liska, Marshall B. Burke, Walter P. Falcon, Joanne C. Gaskell, Scott D. Rozelle, and Kenneth G. Cassman 
This article was published in the November 2007 issue of Environment. Volume 49, Number 9, pages 30-43. Posted with permission.

(c) Heldref Publications, 2007. www.heldref.org/env.php

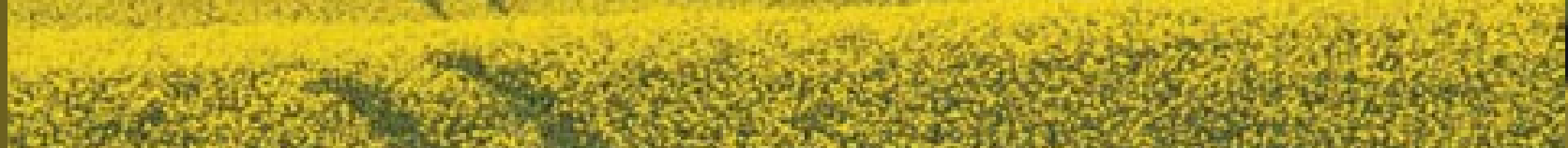

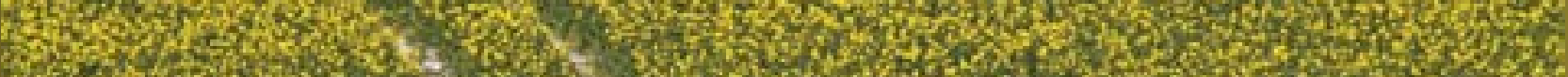

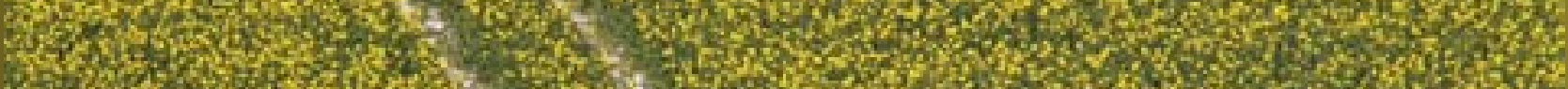

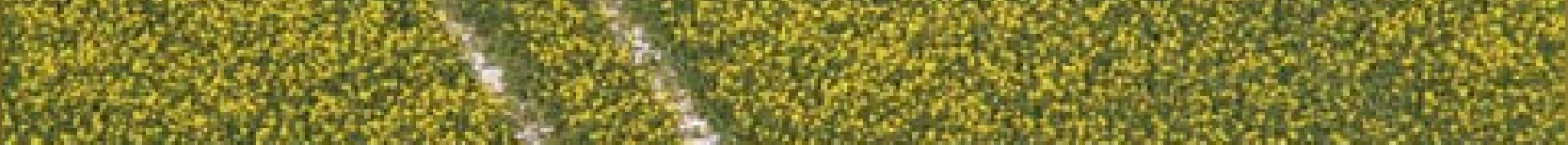

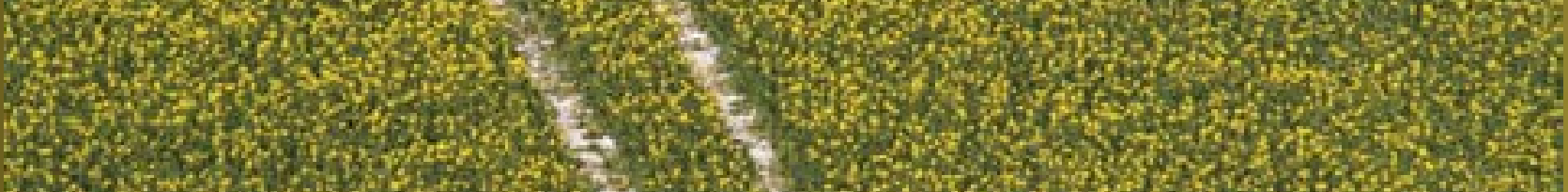

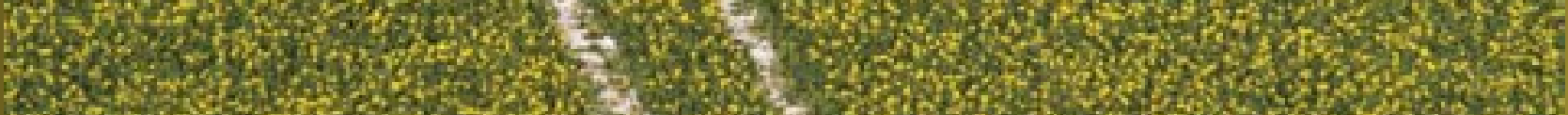
W.

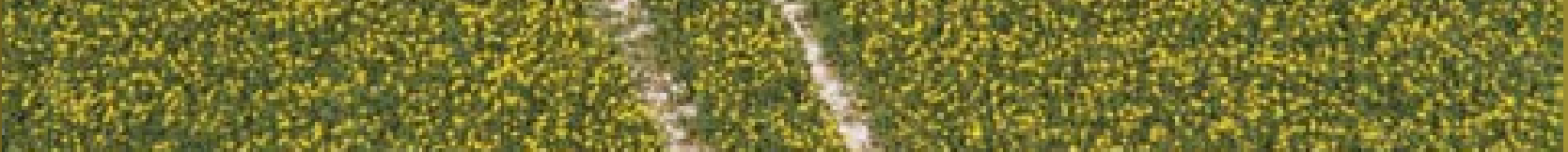

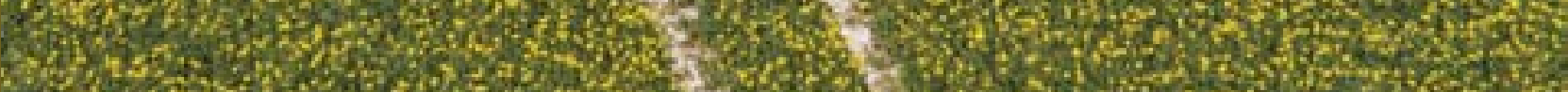

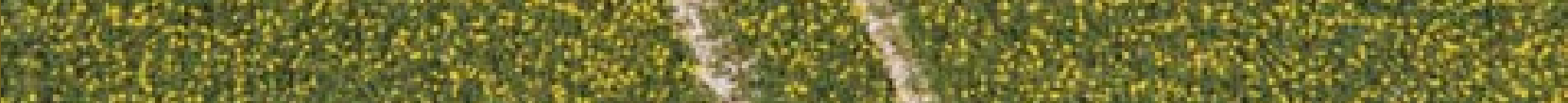
g.

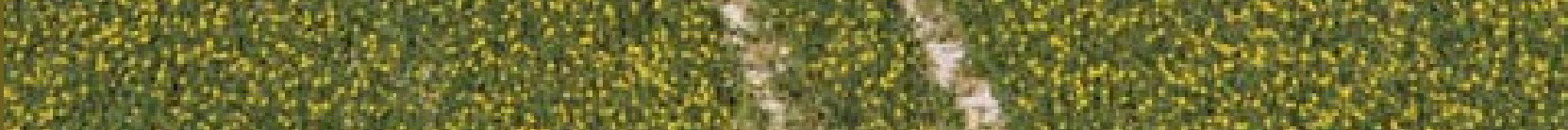

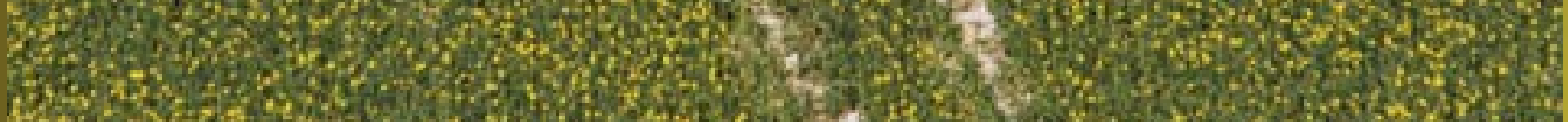

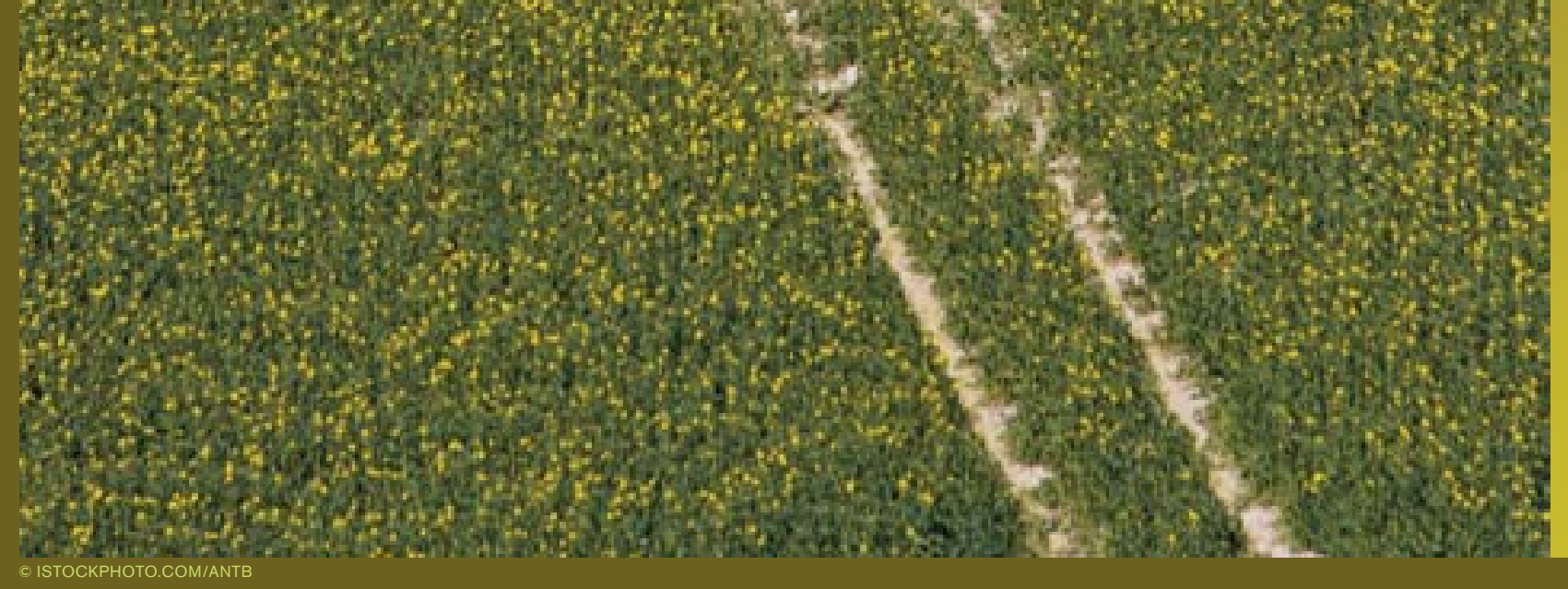


Biofuels growth also will influence efforts to meet two sets of longer-run development targets. ${ }^{5}$ The first encompasses the goals of a "sustainability transition," articulated by the Board on Sustainable Development of the U.S. National Academy of Sciences, which seeks to provide energy, materials, and information to meet the needs of a global population of $8-10$ billion by 2050 , while reducing hunger and poverty and preserving the planet's environmental lifesupport systems. The second is the Great Transition of the Global Scenario Group, convened by the Stockholm Environment Institute, which focuses specifically on reductions in hunger and greenhouse gas (GHG) emissions beyond 2050. As additional demands are placed on the agricultural resource base for fuel production, will ecosystem services (such as hydrologic balances, biodiversity, and soil quality) that support agricultural activities be eroded? Will biofuels development require a large expansion of crop area, which would involve conversion of marginal land, rainforest, and wetlands to arable land? And what will be the net effect of biofuels expansion on global climate change?

Although the questions outnumber the answers at this stage, two trends seem clear: total energy use will continue to escalate as incomes rise in both industrial and developing countries, and biofuels will remain a critical energy development target in many parts of the world if petroleum prices exceed \$55-60 per barrel. Even if petroleum prices dip, policy support for biofuels as a means of boosting rural incomes in several key countries will likely generate continued expansion of biofuels production capacity. These trends will have widespread ripple effects on food security-defined here as the ability of all people at all times to have access to affordable food and nutrition for a healthy life-and on the environment at local, regional, and global scales. The ripple effects will be either positive or negative depending on the country in question and policies in play.

\section{Overriding Engel's Law}

The increasing use of food and feed crops for fuel is altering the fundamental economic dynamics that have governed global agricultural markets for the past century. Investments in crop-based biofuels production are rising steadily as countries seek substitutes for high-priced petroleum products, GHG-emitting fossil fuels, and energy supplies originating from politically unstable countries. ${ }^{6}$ While both energy and food demand rise with income growth, the rate of increase is much greater for energy (see Figure 1 on this page). Declining marginal demand for food in the aggregate with income growth - a pattern widely referred to by the economic development community as Engel's Law-coupled with impressive increases in world food production have led to a steady decline in real food prices over the past century. ${ }^{7}$ To date, Engel's Law has withstood various purported challenges, such as the emergence of China and India into the global economy, the world's rising wealth, and the rapidly expanding demand for meat worldwide.

The same pattern does not hold for energy prices, however, which have oscillated significantly in past decades and increased in real (inflation-adjusted) terms since the mid-1990s (see Figure 2 on page 33). It is clear that until recently, real prices for food and petroleum have not moved systematically in the same direction. But if energy markets begin to determine the value of agricultural commodities, the long-term trend of declining real prices for most agricultural commodities could be reversed and Engel's Law overridden. Over the short term, this reversal, while helping net food producers in poor areas, could have substantial consequences for the world's food-insecure, especially those who consume foods that are direct or indirect substitutes for biofuels feedstocks. Moreover, fuel prices have generally been more volatile than staple commodity prices (as seen in Figure 2). 
For example, crude oil prices have been roughly twice as variable as global maize prices over the last 35 years based on the coefficient of variation. Food price volatility has the largest impact on extremely poor households, who typically spend 55-75 percent of their income on food. ${ }^{8}$

\section{Energy-Agriculture Price Linkages}

Assessing the potential impact of biofuels expansion on global food security requires a sense of which crops, which regions, and what types of demandsupply substitutions are most sensitive to the convergence of energy and agriculture. Because crop-based biofuels are used predominantly for motor fuels, regions with large endemic food insecurity will likely not be substantial sources of biofuels demand or supply in the near term, with a few important exceptions discussed below. Also, conversion of non- food cellulosic crops to biofuels will likely account for only a small proportion of total biofuels production over the next 10 years - and maybe longer (see the box on page 34). Hence, global biofuels production capacity will largely depend on the use of food and feed crops. Based on these assumptions, the primary effect of biofuels development on food security over the next decade will likely be through movements in international food prices induced by activities in middle- and high-income countries. The energy yield of crops is an important determinant of future biofuels development patterns (see the box on page 36). Production costs and returns, as well as market integration between biofuels and fossil fuels, are also fundamental determinants of agro-energy price linkages.

The transmission of energy prices to agricultural markets has traditionally been viewed in terms of energy inputs to agriculture (such as fertilizer, mechanization, and transportation). Now the relationship is determined by the "parity price" between crops and fossil fuels (also referred to as the "break-even price"), defined as the price at which the revenues from crop-based biofuels production are sufficient to cover production costs. ${ }^{9} \mathrm{Sev}$ eral basic models have been developed to project the transmission of energy prices to agricultural markets. ${ }^{10}$ The models show that once differences in energy content are accounted for (for example, a liter of ethanol contains roughly two-thirds the energy of a liter of gasoline), the ethanol price should equal the gasoline price, which itself closely tracks the price of petroleum. The same holds for biodiesel and diesel fuel.

\section{Price Transmission in the International Market}

Although the relationship between energy and agricultural commodity prices is fairly well understood, the transmission

Figure 2. Global trends in prices of food commodities and crude oil 1970-2007

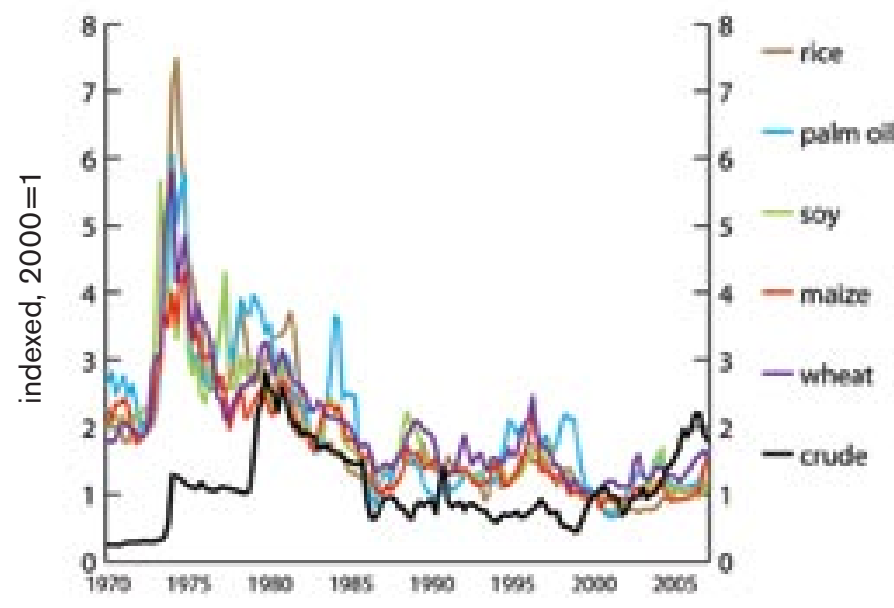

Long-run trends in inflation-corrected prices

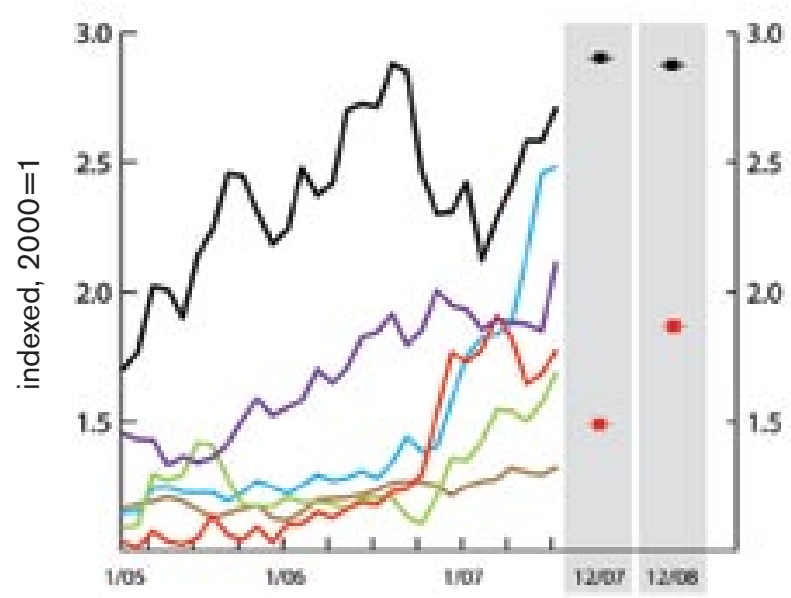

Trends in nominal prices since January 2005 with futures prices for maize and crude for December 2007 and 2008

NOTE: Crude prices are international averages.

SOURCE: Historical data from International Monetary Fund, International Financial Statistics, http://ifs.apdi.net/imf/. Futures data from Chicago Board of Trade, http://cbot.com; and http://tradingcharts.com. 
of agricultural prices from major biofuelsproducing and consuming nations to the international market-and to local markets in food-deficit countries-is less certain. There are several good qualitative models for global agricultural price transmission effects, and some limited quantitative models. ${ }^{11}$ Here we present a basic analytical framework for conceptualizing price transmission dynamics and describe the potential effects on both commodity markets and the environment for four major players in the biofuels market: the United States, Brazil, China, and Indonesia. These countries were selected on the basis of their roles in global production, exports, imports, and potential expansion of production in five key commodities: maize, cassava, sugar cane, soy, and oil palm. The United States and Brazil combined account for more than 90 percent of global bio-ethanol production. China is the third largest bio-ethanol producer, and Indonesia is quickly becoming the biggest oil palm producer globally.

The effects of crop-based biofuels on food prices can be traced through direct and indirect dynamics of production and consumption (see the box on page 38). These dynamics include the responsiveness of demand and supply for the relevant agricultural commodities to prices, which depends in large part on the substitution possibilities in production and consumption (for food, feed, and fuel); the ability of countries to expand land area and raise yields for biofuels feedstocks; market integration between the biofuels and fossil fuels markets; and

border and domestic policy incentives on biofuels and feedstock production and consumption, such as those promoted in the current U.S. energy and farm bills. The short- and long-run effects may differ substantially depending on the biophysical sustainability of individual crop production systems. The long-run effects will also be a function of changing incomes, tastes, biofuels research and development, and infrastructure investments. Finally, in addition to market price dynamics, potential nonmarket costs and benefits to society from expansion of biofuels production capacity include changes in native species' habitat, biodiversity, air and water quality, and net GHG emissions.

\section{U.S. Maize Production for} Domestic Bio-ethanol

\section{CELLULOSIC BIOFUELS POTENTIAL}

Second-generation biofuels from ligno-cellulosic biomass (such as forestry and crop residues, corn stover, and switchgrass) are widely regarded as preferred feedstock for biofuel production because the vast abundance of biomass crops could support a larger biofuel industry than can be supported by food crops alone. ${ }^{1}$ However, current cellulosic biomass-to-fuel conversion processes are still under development, and large-scale harvesting, storage, and refinery systems are not yet cost-effective. Several companies operate pilot-scale facilities and will develop small commercial-scale biorefineries for wood chips, prairie grasses, and crop residues within two to three years. ${ }^{2}$ But even those sources of feedstock are becoming more expensive. Rapid expansion of maize bio-ethanol from grain has raised the price of potential feedstock sources, such as hay and forage crops; for example, the price of maize crop residue used for cattle and dairy feed has doubled in Nebraska during the past year.

Cellulosic biomass is composed of sugar polymers that can be broken down and fermented into ethanol; however, because it provides the structural rigidity for plants and trees, it has evolved to be highly resistant to degradation from predatory organisms. ${ }^{3}$ Enzymes are being developed for ligno-cellulose degradation, but their conversion efficiency is limited and their cost is currently too high for large-scale commercialization. Water requirements for large-scale cellulosic ethanol conversion and infrastructure costs also are not well understood but could be significantly higher than for maize bio-ethanol according to some expert estimates. ${ }^{4}$ Biomass can also be converted to biodiesel via thermochemical processes - thereby avoiding some of the constraints to the large-scale deployment of cellulosic ethanol-but production remains at a pilot scale. ${ }^{5}$ Due to these current constraints, observers predict that mature technology for large-scale deployment of cellulosic biofuels production is at least 10 years away. ${ }^{6}$ During this 10 -year period, biofuels production capacity based on food crops will continue to expand at a rapid pace.

1. For some analysis of cellulosic biofuels, see M. K. Heiman and B. D. Solomon, "Fueling U.S. Transportation: The Hydrogen Economy and Its Alternatives," Environment 49, no. 8 (October 2007): 10-25.

2. B. Hahn-Hagerdal et al., "Bio-ethanol: The Fuel of Tomorrow from the Residues of Today," Trends in Biotechnology 24, no. 12 (December 2006): 549-56.

3. M. E. Himmel et al., "Biomass Recalcitrance: Engineering Plants and Enzymes for Biofuels Production," Science 315, no. 5813 (9 February 2007): 804-7.

4. M. M. Wright and R. C. Brown, "Comparative Economics of Biorefineries Based on the Biochemical and Thermochemical Platforms," Biofuels, Bioproducts and Biorefining 1, no. 1 (September 2007): 49-56.

5. G. W. Huber, S. Iborra, and A. Corma, "Synthesis of Transportation Fuels from Biomass: Chemistry, Catalysts, and Engineering," Chemical Reviews 106, no. 9 (2006): 4044-98.

6. M. E. Himmel et al., note 3 above.
The United States accounts for roughly 40 percent of world maize production (see the table in the box on page 36) and typically contributes $55-60$ percent of total global trade in maize..$^{12}$ As a result, the amount of maize grown in the United States, and the share of maize used for domestic consumption versus exports, has significant impact on international maize prices.

The sustained high price of petroleum in recent years, translating directly into high gasoline prices, has provided impetus for growth in the domestic maize bioethanol industry. Combined with policy incentives that include a $\$ 0.13$ per liter ( $\$ 0.51$ per gallon) blending credit for ethanol, a $\$ 0.14$ per liter (\$0.54 per gallon) tariff on imported ethanol, a 2.5 percent additional duty on the value of imported ethanol, and a mandate to phase out MTBE (methyl tertiary-butyl ether) as a fuel additive (ethanol is a good substitute for MTBE), the domestic industry is expanding rapidly. Annual production of U.S. bio-ethanol was 18.5 bil- 
lion liters in 2006, surpassing Brazil (at 17 billion liters) for the first time. U.S. output is expected to reach 30 billion liters by the end of 2007 and 45 billion liters by the end of 2009. Although the 2006 bio-ethanol output accounts for only 2.5 percent of the country's 530 billion liter annual gasoline consumption on an equivalent energy basis, it is transforming the agricultural sector.

In response to this rapid increase in ethanol production capacity, maize prices rose from $\$ 2.60$ per bushel in July 2006 to $\$ 4.25$ per bushel at the start of planting in March 2007. ${ }^{13}$ The high price caused acreage planted to maize in 2007 to rise 19 percent over 2006 plantings to almost 38 million hectares. ${ }^{14}$ This was the largest area planted to maize since 1944. Most of this expansion came at the cost of soybean plantings; soy acreage declined 15 percent from a record high in 2006 to about 26 million hectares in 2007. Acreage planted to wheat rose 6 percent to about 24 million hectares due to higher prices caused by global supply shortages and increased livestock demand. Perhaps most striking has been the massive appreciation in agricultural land values. The average price of U.S. farmland increased 74 percent between 2000 and 2007 to a record $\$ 4,700$ per hectare. In Iowa-a leading maize-producing state-farmland values rose by roughly $\$ 2,470$ per hectare between 2003 and 2007 to more than $\$ 7,900$ per hectare. ${ }^{15}$

What these changes mean for U.S. maize plantings and international maize prices over the longer run remains uncertain. Maize prices fell in mid-July 2007 to $\$ 3.55$ per bushel due to increased supply, but futures prices for December 2008 are still about $\$ 4.00$ per bushel indicating the strength of expected demand. ${ }^{16}$ Future demand for maize bio-ethanol will depend importantly on consumer preferences, flex-fuel fleet expansion, and infrastructure investments. Investments have already been made in nearly a hundred new bio-ethanol plants throughout the country, paving the road for continued growth in the industry. Moreover, strong policy support for maize bio-ethanol, driven in large part by the underlying

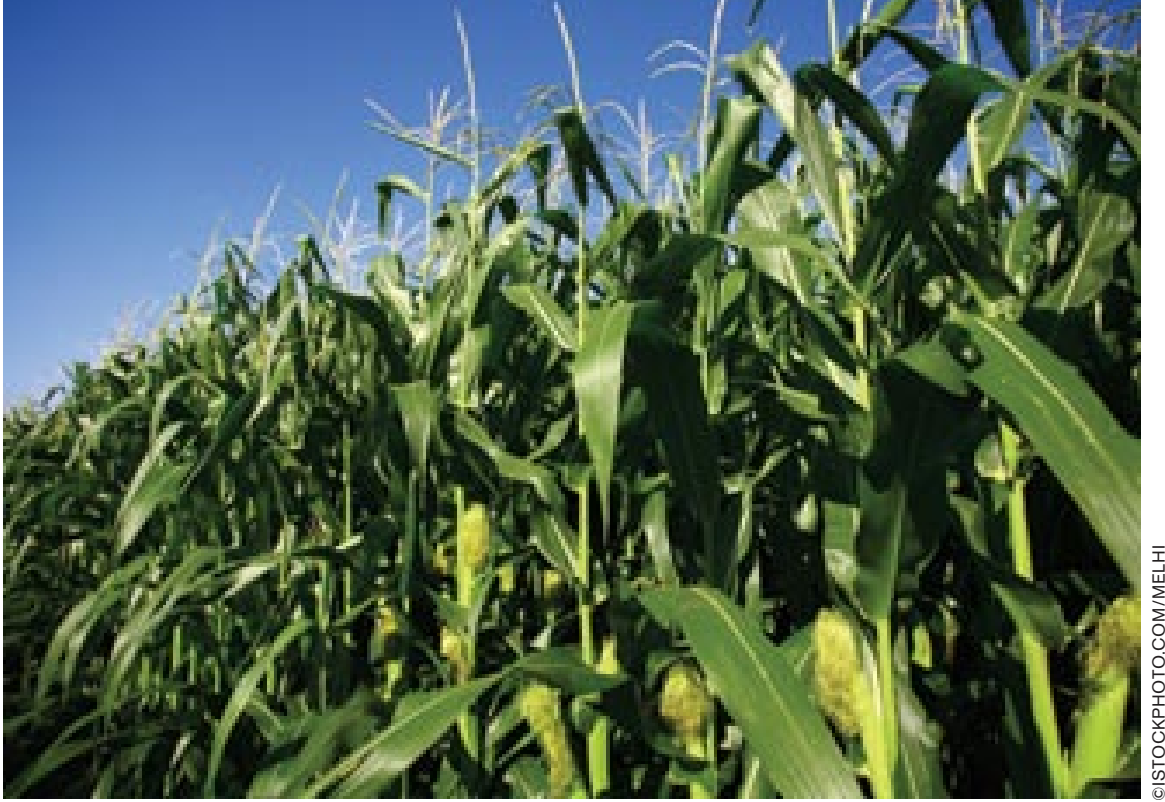

Rising demand for ethanol is causing expansion of maize acres in the United States.

goals of boosting rural incomes in leading farm states and reducing foreign oil imports, will likely bolster future demand for maize.

The real limitation is likely to be on the supply side. Assuming that maize area remains at 38 million hectares with trendline yield growth, about one-third of the maize crop would be needed for ethanol production in 2010, up from 17 percent in 2006. The United States is fundamentally constrained in how much maize can be produced for bio-ethanol by both land area and yield potential. Although maize area expanded this year at the cost of other crops, such as soy, price feedbacks (as described in the box on page 38) limit the amount of area substitution that will occur over time. For example, the potential for a further shift of additional soybean area to maize is likely to be small, if any, because soybean prices have also risen to record levels due to the reduction in soybean area in 2007. Some agricultural lands that were previously removed from production for programs like the Conservation Reserve Program (CRP) are now being brought back into maize cultivation. CRP is at a critical juncture with roughly 400,000 contracts on 11.3 million hectares (24 million acres) scheduled to expire between 2007 and 2010. ${ }^{17}$ In the 2007 Farm Bill, the U.S. Department of Agriculture (USDA) is proposing to give priority on re-authorization of CRP contracts to whole-field enrollment for lands used for biomass production or energy (mainly cellulosic feedstocks). ${ }^{18}$
Unless such biomass systems include a diverse mixture of perennial crop species, introducing monocultures into CRP lands will likely have adverse effects on biodiversity and wildlife habitat-two main CRP goals.

The yield potential for U.S. maize is also limited, despite some private sector claims to the contrary. Maize yield increases will likely remain on their current trajectory of about 1.8 bushels per acre per year $(0.113$ tons per hectare per year) even with current efforts to improve maize hybrids by the major seed companies. Because farmers will be motivated to achieve high yields in response to high maize prices, they are likely to apply greater amounts of inputs, especially fertilizers, since the ratio of maize price to fertilizer cost has increased. Although potentially beneficial for yields, greater fertilizer inputs can also have negative implications for nitrogen and phosphorous loss to groundwater, surface water, and the atmosphere (for example, nitrous oxide, a potent GHG, and regional nitrogen oxide $\left(\mathrm{NO}_{\mathrm{X}}\right)$ pollution) unless farmers also modify methods of fertilizer application to achieve greater efficiency and smaller losses.

\section{Chinese Cassava Imports for Domestic Bio-ethanol}

China presents an interesting case for analyzing the sustainability of biofuel systems because the country is the most rapidly growing consumer of transportation fuels in the world market, is the 
largest contributor of GHG emissions (recently surpassing the United States), and is highly constrained in terms of land resources for food and feedstock production. ${ }^{19}$ Bio-ethanol production in China's officially sanctioned plants during the past 3-5 years has been around 1.3 billion liters. One pro-biofuels faction of the government has argued for ambitious bioethanol targets of up to 6.3 billion liters by 2012 , with 50 percent of the country's motor fuel containing 10 percent ethanol.

There also has been a strong reaction by a separate government faction to rising cereal prices in 2007, however, and to the prospects of allocating a significant share of China's crops to energy production. More than 85 percent of the bio-ethanol produced prior to 2006 has used maize, rice, and cassava as feedstocks. ${ }^{20}$
An ambitious biofuels program would very likely raise China's demand for staple food imports-a potential shift that makes the government increasingly concerned over the domestic food security implications of biofuels growth. As a result, China's top leaders implemented a new policy in 2007 that prevents crop production for bio-ethanol on land traditionally devoted to staple grain production. Instead, minor crops, such as cassava, sweet potato, and sweet sorghum that are grown on marginal soils outside the primary grain belt are being encouraged for use as feedstocks. Of all the non-grain bio-ethanol resources, sweet sorghum is a favorite among agricultural experts due to its low cost and ability to grow on marginal land. ${ }^{21}$ The government aims to produce 3.8 million tons of bio-ethanol annually from sweet sorghum stalks. ${ }^{22}$ This amount translates into 4.8 billion liters of ethanol-almost one-third of Brazil's 2005 production.

Will China be a major bio-ethanol feedstock producer in the future with the ban on maize, wheat, and other staple crops in place? The answer depends in large part on the availability of non-traditional feedstocks, and hence on marginal land for crop production. China currently feeds more than one-fifth of the world's population on only 7 percent of the global cultivated land area. ${ }^{23}$ The country's total arable land is around 130 million hectares, most of which has been used during the past 50 years to meet food demand. Internal official reports suggest that an additional 116 million hectares of marginal land exists-mainly in the south-

\section{ENERGY YIELDS AND GREENHOUSE GAS MITIGATION POTENTIAL OF LEADING BIOFUELS}

First-generation biofuels are produced from conversion of plant starch, sugars, oils, and animal fats into an energy source that can be used in combustion engines to replace gasoline and diesel fuel derived from petroleum. Currently, bio-ethanol is the most widely used biofuel and acts as a substitute for (or is blended with) gasoline. It is produced by fermentation from a number of crops, including sugarcane, maize, cassava, wheat, sugar beet, and sweet sorghum. Biodiesel, widely used in Europe, is made from extracted vegetable oil using crops such as rapeseed, soybean, oil palm, and sunflower. As of 2005, leading bio-ethanol producing countries include Brazil (16.5 gigaliters per year), the United States (16.2), China (2.0), the European Union (1.0), and India (0.3) ${ }^{1}$ Major biodiesel producers include Germany (1.9 gigaliters per year), France (0.5), the United States $(0.3)$, and Italy $(0.2)$.

Among the major feedstock crops, biofuel energy yield (gigajoules per hectare) is greatest for Malaysian palm oil and smallest for Brazilian soybean with a 10-fold difference between the two based on current crop yields and processing yields (see the table at right). On average, the energy yield per hectare from Malaysian oil palm was 1.4-fold greater than the energy yield from Brazilian sugarcane, 2-fold greater than U.S. maize, 4-fold greater than Brazilian cassava. ${ }^{2}$ It should be noted, however, that these figures represent gross biofuel energy yields; they do not account for energy expended in the cultivation, harvesting, and processing of the crops, which would reduce their net energy yields.

Because biofuels recycle atmospheric carbon dioxide, they reduce greenhouse gas (GHG) emissions relative to petroleum fuels; however, fossil fuel energy inputs used in the biofuel production lifecycle lower the GHG mitigation potential of biofuels. After accounting for energy inputs, Brazilian sugarcane bio-ethanol has the greatest net GHG mitigation potential and is estimated to reduce GHG emissions by approximately 100 percent compared to gasoline on an energy-equivalent basis. ${ }^{3}$ Maize bio-ethanol, soybean biodiesel, and cassava bio-ethanol have been shown to reduce net GHG emissions compared to gasoline by similar amounts: 13-52 percent, 41 percent, and 40 percent respectively. ${ }^{4}$ The GHG mitigation potential of oil palm biodiesel could be as high as sugarcane bio-ethanol for established plantations, but forest clearing for new plantation establishment, particularly by burning, could release stored carbon and lead to significant net increases in GHG emissions relative to petroleum use. ${ }^{5}$

1. Worldwatch Institute, Biofuels for Transportation: Global Potential and Implications for Sustainable Agriculture and Energy in the 21st Century (Washington, DC, 2006).

2. A. E. Farrell et al., "Ethanol Can Contribute to Energy and Environmental Goals" Science 311, no. 506 (27 January 2006): 506-8; I. Macedo, M. Lima Verde, and J. Azevedo, Assessment of Greenhouse Gas Emissions in the Production and Use of Fuel Ethanol in Brazil, Government of the State of São Paulo and Secretariat of the Environment (São Paulo, Brazil, 2004); T. L. T. Nguyen, S. H. Gheewala, and S. Garivait, "Full Chain Energy Analysis of Fuel Ethanol from Cassava in Thailand," Environmental Science \& Technology 41, no. 11 (2007): 4135-42; and J. Hill et al., "Environmental, Economic, and Energetic Costs and Benefits of Biodiesel and Ethanol Biofuels," Proceedings of the National Academy of Sciences 103, no. 30 (2006): 11206-10.

3. Macedo, Lima Verde, and Azevedo, note 2 above

4. Farrell et al., note 2 above; M. Wang, M. Wu, H. Huo, "Life-cycle Energy and Greenhouse Gas Emission Impacts of Different Corn Ethanol Plant Types" Environmental Research Letters 2 (2007): 024001; Hill et al., note 2 above; Z. Hu et al., "Economics, Environment, and Energy Life Cycle Assessment of Automobiles Fueled by Bio-ethanol Blends in China," Renewable Energy 29, no. 14 (2004): 2183-92.

5. M. B. Wahid, C. K. Weng, C. Y. May, and C. M. Chin, "The Need to Reduce National Greenhouse Emissions: Oil Palm Industry's Role," Journal of Oil Palm Research special issue (2006): 1-23. 
west-and that roughly 20 percent (23 million hectares) of this land is biophysically suitable for feedstock production. Although possible, it is doubtful that such vast tracts of land would be suitable for crop-based feedstock production, particularly since much of the area is on sloping land prone to serious erosion.

Large areas of marginal land have also been put into the Grain for Green
Program (China's version of the Conservation Reserve Program), and the government is committed to preventing this land from being planted in row crops. The environmental costs of converting vast areas of marginal land to crop production are only beginning to be explored. Moreover, the economic feasibility of developing these areas for feedstock production is debatable since the unskilled wage is rising, which could make the costs of cultivating and transporting nontraditional crops-all labor-intensive activities-prohibitively expensive.

As a result of these constraints, China is looking for feedstock production opportunities outside its borders. Some internal reports suggest that the China Oil and Food Corporation is investing in several Southeast Asian countries (Laos, Cambo-

\section{Agricultural production of five major feedstocks and biofuel energy yields}

\begin{tabular}{|c|c|c|c|c|c|c|c|c|c|c|}
\hline \multirow{3}{*}{$\begin{array}{l}\text { Biofuel type } \\
\text { Biofuel crop } \\
\text { Country, top two } \\
\text { crop producers in } 2005\end{array}$} & \multicolumn{6}{|c|}{ Bio-ethanol } & \multicolumn{4}{|c|}{ Biodiesel } \\
\hline & \multicolumn{2}{|c|}{ Maize } & \multicolumn{2}{|c|}{ Sugarcane } & \multicolumn{2}{|c|}{ Cassava } & \multicolumn{2}{|c|}{ Soybean } & \multicolumn{2}{|c|}{ Oil Palm } \\
\hline & $\begin{array}{l}\text { United } \\
\text { States }\end{array}$ & China & Brazil & India & Nigeria & Brazil & $\begin{array}{l}\text { United } \\
\text { States }\end{array}$ & Brazil & Malaysia & Indonesia \\
\hline $\begin{array}{l}\text { Total production }{ }^{\mathrm{a}} 2005 \text {, in } \\
\text { million metric tonnes }\end{array}$ & 280 & 133 & 420 & 232 & 42 & 26 & 83 & 50 & 76 & 64 \\
\hline $\begin{array}{l}\text { Percentage of world } \\
\text { production, }{ }^{\text {a }} 2005\end{array}$ & 40 & 19 & 33 & 18 & 20 & 12 & 39 & 24 & 44 & 37 \\
\hline $\begin{array}{l}\text { Average crop yield, }{ }^{a} \\
2003-2005, \text { in } \\
\text { metric tonnes per hectare }\end{array}$ & 9.4 & 5.0 & 73.5 & 60.7 & 10.8 & 13.6 & 2.7 & 2.4 & 20.6 & 17.8 \\
\hline $\begin{array}{l}\text { Conversion yield }{ }^{\mathrm{b}} \text { in liters } \\
\text { per metric ton }\end{array}$ & 399 & 399 & 74.5 & 74.5 & 137 & 137 & 205 & 205 & 230 & 230 \\
\hline $\begin{array}{l}\text { Biofuel yield }{ }^{c} \text { in liters per } \\
\text { hectare }\end{array}$ & 3751 & 1995 & 5476 & 4522 & 1480 & 1863 & 552 & 491 & 4736 & 4092 \\
\hline $\begin{array}{l}\text { Energy yield }{ }^{d} \text { in } \\
\text { gigajoules per hectare }\end{array}$ & 79.1 & 41.1 & 116 & 95.4 & 31.2 & 39.3 & 18.2 & 16.1 & 156 & 135 \\
\hline $\begin{array}{l}2005 \text { petroleum } \\
\text { replacement, }{ }^{e} \text { percent of } \\
\text { total petroleum use }\end{array}$ & 2.0 & 2.4 & 40.4 & 1.8 & - & - & 0.1 & - & - & - \\
\hline \multicolumn{11}{|c|}{$\begin{array}{l}\text { a Food and Agriculture Organization of the United Nations, FAOSTAT, http://faostat.fao.org/ (accessed } 4 \text { August 2007). } \\
\text { b Feedstock conversion yields for maize: H. Shapouri and P. Gallagher, } 2002 \text { Ethanol Cost-of-Production Survey, USDA-ERS, AER } \\
\text { no. } 841 \text { (Washington, DC: United States Department of Agriculture, Office of the Chief Economist, Office of Energy Policy and New } \\
\text { Uses, 2005), http://www.usda.gov/oce/reports/energy/USDA_2002_ETHANOL.pdf (accessed 25 September 2006); sugarcane: } \\
\text { J. Goldemberg, "Ethanol for a Sustainable Energy Future," Science 315, no. } 5813 \text { (9 February 2007): 808-10; cassava: Nguyen et } \\
\text { al., note } 2 \text { at left; soybean: Hill et al., note } 2 \text { at left; oil palm: calculated, } 20 \text { percent of harvested mass is crude oil, } 1: 1 \text { conversion } \\
\text { of crude palm oil-to-biodiesel (Dr. Ma Ah Ngan, Malaysian Palm Oil Board, in personal communication with the authors, September } \\
\text { 2006). Palm oil density is } 0.87 \text { kilograms per liter. } \\
\text { c Biofuel yield = crop yield x conversion yield. } \\
\text { d Gross energy yield; lower heating value of ethanol } 21.1 \text { megajoules per liter or biodiesel } 32.9 \text { megajoules per liter x conversion yield x } \\
\text { crop yield. } \\
\text { e Biofuel production capacity converted to energy-equivalents of gasoline (or diesel). Petroleum replacement based on gasoline and } \\
\text { diesel use in } 2003 \text { for each respective country. Worldwatch Institute, note } 1 \text { at left; and Energy Information Administration, Interna- } \\
\text { tional Energy Annua/ 2004, DOE/EIA-0384 (Washington, DC, 2005). }\end{array}$} \\
\hline
\end{tabular}


dia, Malaysia, Indonesia, and the Philippines) for biofuels feedstock production; it already leases hundreds of hectares in Laos for cassava production. There also is speculation that the company is buying property in the Philippines to plant oil palm. These arrangements-if they come to fruition-will have wide-ranging implications for rural incomes, employment, trade, and the environment for the participating countries.

From a global food security perspective, the largest impact of China's activities might be seen through the international cassava market. In the past, cassava has been traded internationally in small volumes, mainly for feed, and subject to a peculiar set of EU trade policies. ${ }^{24}$ World trade in cassava has risen recently to 8-10 percent of global production, reflecting China's entrance into the world market for livestock feed and biofuel feedstocks. China's cassava imports account for roughly two-thirds of total world trade and now stand at 12.5 million metric tons annually, up from 2 million metric tons in $2000 .^{25}$ Virtually all these imports are sourced from Southeast Asia, with Thailand as the largest world exporter (and re-exporter). If China's cassava demand continues to increase in the international market, it is expected that cassava prices will rise significantly. Will the international livestock sector or the world's poor be more vulnerable to the expected price increase? Understanding the ripple effects of China's demand on poor net consumers and producers of cassava in regions as distant as Sub-Saharan Africa will require further analyses.

\section{Expansion of Brazilian Sugarcane and Soy}

Brazil has been the world's largest producer and consumer of bio-ethanol for the past 25 years and has only recently been surpassed by the United States. The country is currently the only major exporter of bio-ethanol. Strong government support and a tropical/subtropical climate to which sugarcane is well adapted make Brazil's the world's most technologically sophisticated, energy-efficient, and market-integrated biofuels industry. ${ }^{26}$ Sugarcane bio-ethanol now accounts for 40 percent of automobile motor fuel in the country and requires about 54 percent of the sugarcane crop. Overall, Brazil accounts for one-third of global sugarcane production, which is produced on 5.6 million hectares, or about 10 percent of the country's total existing cropland. With rapidly growing internal and export mar- kets for ethanol, there are now plans to expand production by adding another 136 bio-ethanol plants to the existing stock of 357 facilities. $^{27}$

In comparison to the United States and China, expansion of Brazilian biofuels production is significantly less constrained by land. Over the next 10 years, sugarcane-cropped area is estimated to reach roughly 10 million hect-

\section{DIRECT AND INDIRECT EFFECTS OF BIOFUELS EXPANSION}

Large-scale biofuels expansion will alter prices of staple food crops through direct and indirect channels, as illustrated by the hypothetical example of maize bio-ethanol in the United States (see the figure below). Rapid growth in maize bio-ethanol leads to price increases in maize, wheat, and soy in the absence of significant yield growth or crop area expansion. The ripple effects are seen in pristine land areas cleared for agriculture (for example, conservation land in the United States or rainforests in Brazil), on the livestock sector, and on consumers of these staple food commodities. The magnitude of effects depends on adjustments in grain, oilseed, and livestock markets, and on price transmission domestically and internationally.

\section{Dynamics of a biofuels-induced increase in demand for maize, wheat, and soybeans in the United States}

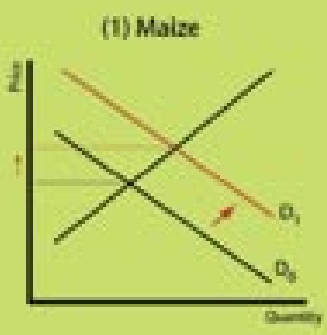

Rising demand for maize leads to growth in supply along the curve that includes production a higher marginal costs.

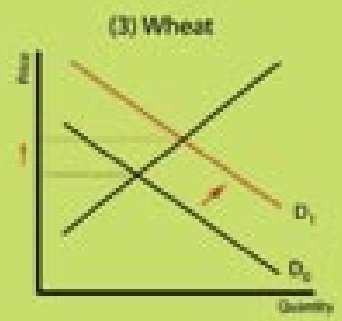

Higher maize prices increase demand for wheat in livestock markets, causing wheat prices to rise.

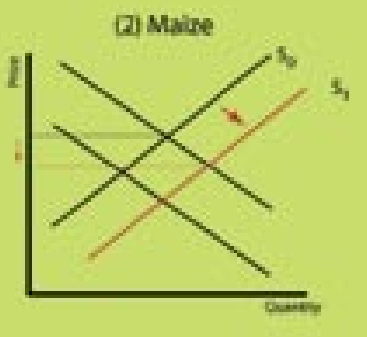

Longer-run shift in supply due to technical change induced by higher prices.

NOTE: $\mathrm{D}=$ demand curve; $\mathrm{S}=$ supply curve. 
ares. ${ }^{28}$ Although current production is primarily localized in the southern state of São Paolo, the anticipated expansion will likely displace livestock pastures and other crops, thus indirectly raising distant Amazon deforestation. ${ }^{29}$

Soybean cultivation in Brazil for feed and biodiesel poses a more direct threat to the Amazonian rainforest in the central state of Mato Grasso. ${ }^{30}$ Soybean expansion has moved northward over the last 30 years and is projected by some to reduce the Amazonian rainforest by 40 percent by $2050 .{ }^{31}$ Although livestock expansion has historically been the main cause of Amazon deforestation, soybean planting often follows livestock pastures and more recently has been a direct cause of deforestation. ${ }^{32}$ The savannahs of the Brazilian cerrado and the Chaco forest of Argentina, Paraguay, and Bolivia are similarly threatened by crop expansion. ${ }^{33}$ The cerrado is experiencing dramatic loss of 2.2-3 million hectares of native habitat per year. If soybean prices stay high as a result of the large shift of U.S. soybean area to maize and increased demand for biodiesel production, there could be a new burst of soybean expansion into the Amazon rainforest and cerrado. The expansion of both sugarcane and soybean will thus have a significant impact on biodiversity and, through deforestation, the release of carbon stored in forest biomass and soil. ${ }^{34}$ Soil nutrient and hydrological balances within the Amazonian basin are also likely to change at a regional scale, raising questions about the sustainability of cropping systems in the region over the long run.

\section{Indonesian Oil Palms for Global Biodiesel}

The production of oil palm in Indonesia for biodiesel raises many of the same issues as the Brazil case. Dubbed "green gold," Indonesian oil palm yields a phenomenal 17.8 tons per hectare and presently commands a price of more than US\$750 per ton. ${ }^{35}$ Though Malaysian yields are higher on average, Indonesia benefits from abundant land resources and lower wages. Production costs in Indonesia are around $\$ 185$ per hectare, compared

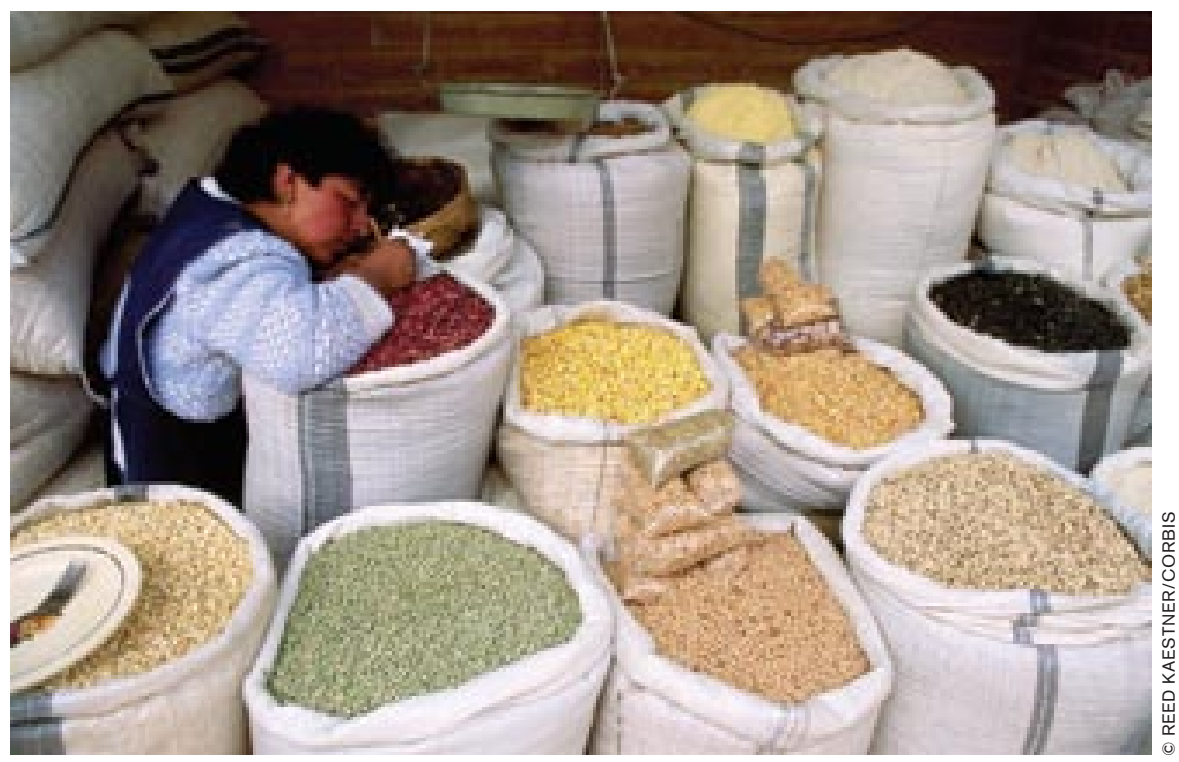

The supply of food grains that will make it all the way to markets such as this one in Ecuador will depend on the global crop demands of the alternative fuel industry.

to $\$ 226$ per hectare for Malaysian palm oil. ${ }^{36}$ As a result, Indonesia is expected to overtake Malaysia in 2007 as the world's largest palm oil exporter.

As the cheapest vegetable oil source in the global market, palm oil is ideally suited as a biodiesel feedstock. Both Indonesia and Malaysia have previously made large commitments to the industry, each having agreed to use 6 million metric tons of palm oil (about 40 percent of total output) for biodiesel production. ${ }^{37}$ Ultimately, the relative prices of crude and vegetable oil, along with subsidy and trade policies in the United States and European Union, will determine the size of Indonesia's and Malaysia's export markets and, in turn, the magnitude of investments in oil palm plantations.

Environmental and social justice concerns threaten to limit palm oil's market potential. Federal plans, including one to convert 5 million hectares of central Borneo rainforest to oil palm, typically do not include environmental audits or satisfactory mechanisms for resolving land conflicts. Even plans that are carefully conceived at the federal level may be overridden at the local level. Decentralization of government authority in Indonesia from the federal to provincial levels has created confusing and conflicting land-use plans and legal structures and has led to many disputes-sometimes violent-with local inhabitants. Moreover, the volume of palm oil needed to meet a biodiesel refinery's profitability criteria favors large-scale, vertically integrated companies. Fitting smallholders into biodiesel production systems is a challenge for Indonesian policymakers.

The most serious environmental problems stem from converting rainforests to oil palm plantations. ${ }^{38}$ Despite laws to the contrary, land is often cleared by fire, resulting in regional air pollution and a substantial release of carbon from standing biomass and soil, particularly when peat areas are converted. Forest conversion also destroys critical habitats for endangered orangutans and a tremendous array of other species. ${ }^{39}$ Moreover, palm oil mill effluents pollute waterways, further damaging native species' (and human) habitat. In response to these problems, the Roundtable on Sustainable Palm Oil-a group of major producers and international and local nongovernmental organizations-was initiated in August 2003 to help resolve issues of land tenure and environmentally destructive management practices. ${ }^{40}$ This process has created an essential dialogue and a set of guiding principles, although smallholder producers remain underrepresented. 
An additional challenge for policymakers is the effect of rising palm oil prices on poor households. Speculation over biodiesel production in Indonesia and other countries helped drive crude palm oil prices up more than 80 percent between mid-2006 and mid-2007. In 2005 fats and oils comprised 3 percent of the household budget for the poorest quartile of the Indonesian population.
This share had been falling with rising incomes, but it is now rising again due to the crude palm oil price spikes. ${ }^{41}$ In response to social unrest over higher cooking oil prices, the federal government has increased the export tax on palm oil from 1.5 percent to 6.5 percent and is considering a proposal to require that 3.3 million metric tons (minimum) of palm oil be sold for domestic use.
Blending mandates have also fallen from 5 percent to 2.5 percent. $^{42}$ The impacts of higher palm oil prices on future biodiesel investments, the availability of food-based oils in the global market, and fat intake by the world's poorest consumers remain uncertain. It is clear, however, that biofuels growth is already transforming the global vegetable oils sector.

\section{Table 1. Predictions of price changes under various biofuels-related scenarios}

\begin{tabular}{l} 
Source \\
\hline M. W. Rosegrant, S. Msangi, T. Sulser, and \\
R. Valmonte-Santos, Biofuels and the Global \\
Food Balance (Washington, DC: International \\
Food Policy Research Institute, 2006).
\end{tabular}

Food Policy Research Institute, 2006).

\begin{tabular}{l} 
Scenario \\
$\begin{array}{l}4 \text { percent U.S. gasoline replacement by biofu- } \\
\text { els, } 20 \text { percent elsewhere, up to } 58 \text { percent in } \\
\text { Brazil (biodiesel in EU, ethanol elsewhere); no } \\
\text { technology improvement, projected to } 2020 .\end{array}$ \\
\hline $\begin{array}{l}\text { Same as above, but with cellulosic technology } \\
\text { online by } 2015, \text { and crop productivity improve- } \\
\text { ments, projected to } 2020 .\end{array}$
\end{tabular}

M. Von Lampe, Agricultural Market Impacts of Future Growth in the Production of Biofuels (Paris: Working Party on Agricultural Policies and Markets, AGR/CA/APM(2005) 24/FINAL Committee on Agriculture, Organization for Economic Cooperation and Development, 2006).

Food and Agricultural Policy Research Institute (FAPRI), Implications of Increased Ethanol Production for U.S. Agriculture (Columbia, MO: University of Missouri, FAPRI-UMC Report \#10-05 2005)

A. Elobeid, and S. Tokgoz, Removal of U.S. Ethanol Domestic and Trade Distortions: Impact on U.S. and Brazilian Ethanol Markets (CARD Working Paper 06-WP 427, Center for Agricultural and Rural Development, lowa State University, 2006).

U.S. Department of Agriculture, Agricultural Baseline Projections: U.S. Crops, 20072016, http://www.ers.usda.gov/Briefing/ Baseline/crops.htm.

J. N. Ferris and S. V. Joshi, "An Econometric Analysis of the Impact of the Expansion in the U.S. Production of Ethanol from Maize and Biodiesel from Soybeans on Major Agricultural Variables, 2005-2015," in J. Outlaw, K. J. Collins, and J. A. Duffield eds., Agriculture as a Producer and Consumer of Energy (Cambridge, MA: CABI Publishing, 2006).

FAPRI, Baseline Update for U.S. Agricultural Markets (Columbia, MO: University of Missouri, FAPRI-UMC Report \#12-06 2006).
Constant $\$ 60$ per barrel price of oil, projected to 2014 .

"Growth in line with publicly stated goals"; 28 gigaliters in the United States by 2012, projected to 2014.

7 billion gallon U.S.-produced ethanol use, 7.5 billion gallon biodiesel and ethanol imports by 2012, projected from 2012 to 2015 , relative to baseline.

Long-run oil price of $\$ 60$ per barrel with the United States using 30 billion gallons of ethanol, projected to 2015 , relative to baseline.

12 billion gallons of ethanol, 700 million gallons of biodiesel in the United States, projected to 2016.

5.7 billion gallons of ethanol, 300 million gallons of biodiesel in the United States by 2015, projected relative to baseline.
6.6 billion gallons ethanol in Brazil, 0.8 billion gallons ethanol in EU, 8 billion gallons in United States; $4.9 \mathrm{mmt}$ rapeseed oil in EU, projected to 2015-2016, relative to today.

\section{Projected price increase}

Corn, 41 percent; wheat, 30 percent; soy (oilseeds) 76 percent; sugar (sugarcane), 66 percent; cassava, 135 percent

Corn, 23 percent; wheat, 16 percent; soy (oilseeds) 43 percent; sugar (sugarcane), 43 percent; cassava, 54 percent

Corn, 19 percent; wheat, 17 percent; soy (oilseeds) 19 percent; sugar, 20 percent; vegetable oil, 22.3 percent

Corn, 2.5 percent; wheat 4.4 percent; soy (oilseeds) 1.1 percent; sugar, 4 percent; vegetable oil, 12.9 percent

Corn, 5.4 percent; wheat, 1.7 percent; soy, -0.2 percent; sorghum, 4.2 percent

Corn, 58 percent; wheat, 20 percent; soy (meal) -42 percent; soy (oil) 20 percent

Corn, 65 percent; wheat, 33 percent; soy, 19 percent; sugar, -8 percent; sorghum, 64 percent

Corn, 6 percent; soy (meal), -5 percent; soy (oil), 31 percent

Corn, 30 percent; wheat, 11 percent; soy, 2 percent; sugar, 21 percent (FOB Caribbean); palm oil, 17 percent 


\section{Food Security Implications}

The above case studies indicate that biofuels are causing an abrupt increase in demand for agricultural commodities traditionally used for food and feed, which is placing upward pressure on crop prices. Whether future price increases and subsequent adjustments in demand and supply occur at local, regional, or global scales has yet to be determined. Price transmission models developed for agricultural trade policy analysis provide some indication of scale; for example, some such models suggest strong national and global price transmission for maize and cassava with the exception of some very lowincome landlocked countries. ${ }^{43}$

There are also a number of studies completed and in progress that project future agricultural prices related to biofuels development. Table 1 on page 40 summarizes the price forecasts for several of these studies. Although they are not directly comparable to one another given differences in model design, scope, and time horizon, they offer a glimpse at where prices might move under various scenarios of biofuels expansion. These studies generally anticipate large increases in cassava prices, moderate to large increases in maize prices, slightly smaller increases in wheat prices, small to large increases in sugar prices, moderate increases in vegetable and palm oil prices, and ambiguous effects on soybean prices as meal and oil prices move in opposite directions. Unfortunately, these models do not project direct transmission from the international market to particular countries.

In addition to the anticipated price increases for virtually all commodities, three other conclusions seem clear from Table 1. First, the variance in price predictions tends to swamp the mean. Second, price variability is not treated in most models. And finally, the focus of most projections is on a limited number of scenarios surrounding industrial-world production. Few studies attempt to quantify the various linkages between biofuels development and food-insecure people in low-income countries. As a first cut, some studies have inferred the potential link- ages by dividing countries among food and energy importers and exporters by income group, but this approach does not embed the dynamics of rural development that might result from higher agricultural prices. ${ }^{44}$ Extensive analytical work based on global and national data sets and integrated dynamic models is needed to quantify these linkages more precisely.

Understanding what poor people eat and how they spend their money on food provides additional insight into the potential food security consequences of biofuels growth. When crops are ranked according to their contribution to average calorie consumption by the world's food-insecure population, the main feedstocks appear near the top of the list. Sugarcane, maize, cassava, palm oil, soy, and sorghum comprise about 30 percent of mean calorie consumption by people living in chronic hunger. ${ }^{45}$

In some countries, such as Guatemala, Malawi, and Tanzania-all countries with high rates of malnutrition-people derive one-third or more of their calories from maize. ${ }^{46}$ The poorest segments of these populations are particularly vulnerable to increasing maize prices. For example, World Bank survey data from Tanzania indicate that the poorest quintile spend five times as much on maize

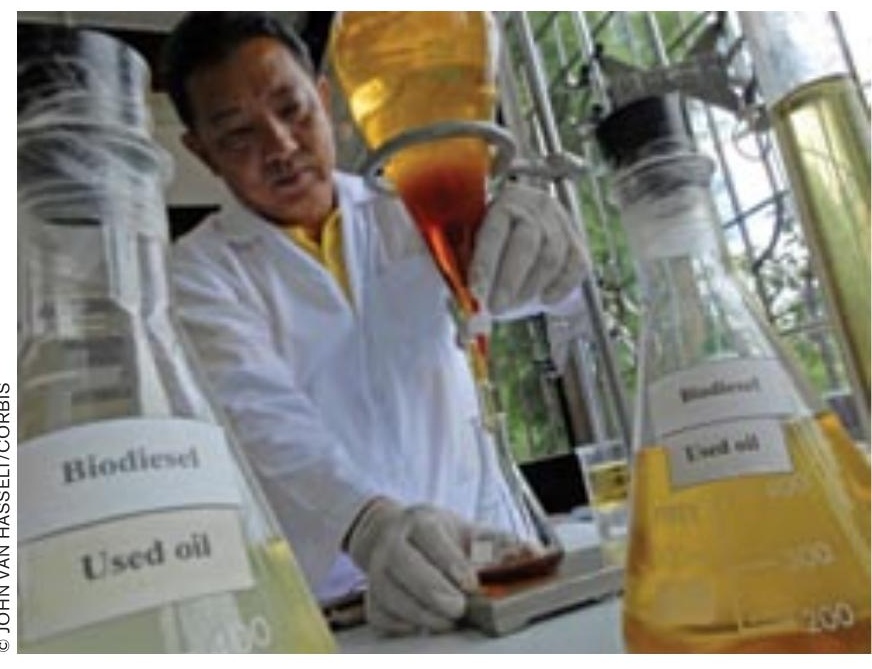

Biodiesels may be the wave of the future, but at what cost to food security?

compared to the richest as a percent of total expenditure, and roughly twice the mean. ${ }^{47}$ The same data also show that the poorest spend 80 percent of their budget on food, as opposed to 60 percent for the richest.

Other key commodities in the biofuels market are also important in the diets of the poor. Cassava accounts for onethird and one-half of calories consumed in the Democratic Republic of Congo and Ghana, respectively, and sugar accounts for a strikingly high share of calories consumed in Brazil, Bolivia, and Guatemala. Palm oil does not represent a particularly large share of total calories consumed in poor countries, but it does account for a large share of the fats consumed. For example, in Liberia and Sierra Leone, two of the poorest countries in the world, palm oil accounts for 40 percent of the fats consumed on average, and in Bangladesh and Kenya, the rate is 20 percent. $^{48}$

If agricultural commodity prices remain high, the amount of humanitarian food aid available for extremely poor countries is also likely to be affected. Food aid shipments from the United States are inversely correlated with commodity prices; that is, when cereal prices are high - and when poor consumers are apt to need aid the most-food aid shipments are low, and vice versa. ${ }^{49}$ In the short run, a sharp decline in food aid shipments could severely impact those in need. In Malawi and Zimbabwe, about one-fifth of total coarse

grain consumption comes from food aid; in Guatemala the share is one-tenth. Food aid is seldom a long-run solution to chronic hunger, and perhaps with higher commodity prices, there will be greater incentives to invest in agricultural development in poor countries. The impact of humanitarian aid is likely to be most acute in the short run as adjustments are being made.

One of the greatest uncertainties regarding the ripple effects of biofuels growth on global food security is, indeed, how agricultural development patterns will respond to rising prices in international markets. Will cassava production expand in extremely poor countries like Laos and Cambodia in response to China's demand and lift rural households out of pover- 
ty? Will low-income maize producers in southern and eastern Africa find richer domestic markets for their crops with the decline in U.S. food aid? Will there be a revival of agricultural investments in lowincome food deficit countries where policy attention has turned elsewhere in recent decades? These questions are not easy to answer at this early stage of the biofuels revolution and will depend on economic incentives as well as governance in the world's poorest countries.

\section{Conclusions and Policy Implications}

As 2007 draws to a close with the biofuels boom in play, four conclusions seem clear. First, rapid growth in the bioethanol and biodiesel markets is placing increasing demands on key agricultural commodities that have traditionally been used for food and feeds. As a result, agricultural commodity prices for the main feedstocks are rising in international markets, inducing substitutions in production and consumption that are causing price increases in a wider array of agricultural markets. It is very likely that the demand for biofuels and related effects on agricultural prices will continue as long as petroleum prices remain above \$55-60 per barrel. A second, related point is that political economy interests in some important countries and regions such as the United States, China, Brazil, Indonesia, and the European Union will likely perpetuate growth in biofuels production capacity over the medium term regardless of short-run fluctuations in petroleum prices. Such interests include goals to revitalize rural economies, support agricultural constituencies, generate foreign investment and foreign exchange reserves, and create globally competitive biofuels industries in the face of multiple incentives to reduce fossil fuel use. Hence even if petroleum prices fall, demands on the global agricultural sector will remain strong.

Third, the leading agricultural commodities used as feedstocks, such as sugarcane, maize, oil palm, and cassava, are also those that comprise a relatively large share of the diets of food-insecure people worldwide. Although most poor people live in rural areas and are dependent on agriculture, the world's food-insecure population is comprised mainly of net consumers. The global food security implications and tradeoffs of biofuels development thus deserve serious policy attention.

Finally, biofuels growth will rely primarily on agricultural commodities as opposed to cellulosic feedstocks over the coming decade and will be constrained largely by food crop production capacity. Agricultural land area is limited in most regions, and where expansion is possible (for example, Brazil and Indonesia), the environmental costs related to forest clearing, GHG emissions, biodiversity loss, hydrological changes, and reduced water and soil quality could potentially offset the benefits from biofuels. In landconstrained regions, raising yields through ad hoc use of higher fertilizer rates and water resources without improved technologies to increase input efficiencies also creates environmental problems. ${ }^{50}$ The extent to which biofuels growth is compatible with sustainable development therefore remains questionable without a substantial increase in research that explicitly targets environmentally sound practices for producing crop-based feedstocks, at least until second-generation technologies become commercially viable at a large scale. Even then, land conversion to cellulosic feedstocks will have both positive and negative environmental impacts.

Several additional uncertainties related to the dynamics of the global economy loom large as the biofuels market unfolds. Will poor, small farmers in South Asia benefit from higher world prices? Will poor net consumers of cassava or maize in sub-Saharan Africa be affected by price increases caused by growth in the United States or Chinese bio-ethanol markets? Even today, the transmission of agricultural commodity prices from the international to the local scale, particularly in low-income, food-deficit regions where the chronically hungry are most affected, is not clear. Moreover, it is not obvious what types of substitutions poor consumers are making or are likely to make in their diets with price increases in staple foods.

The wide array of potential interactions over space and time in the world food economy requires policy analyses that are neither black box models nor simplistic partial equilibrium solutions. While these analyses are being pursued, continued efforts should be promoted to address food insecurity regionally and globally through agricultural investments in low-income countries, particularly where governance structures are adequate to permit broadly distributed rural growth. It is likely that aggregate investments in agricultural development at the national or regional level will be more successful in reducing rural poverty than individual biofuels investments by specific companies or groups - the latter often resulting in a silver bullet approach with limited reach to poor populations.

Growth in biofuels production capacity offers many promises, but also many threats, for the future course of sustainable development. The design and implementation of sustainability audits is critical as the biofuels industry develops, with clear metrics for evaluating the environmental and social consequences of biofuels and feedstock production and for ensuring that management and governance practices are compatible with pre-determined sustainability goals. The Roundtable on Sustainable Palm Oil provides a good model for such an audit process and is now being used to reevaluate a large proposed U.S. investment in a palm oil-based biodiesel plant. ${ }^{51}$ The European Union is also in the process of creating a set of biofuels sustainability criteria that will be applied to domestic production and imports in its efforts to reach its 10 percent target by $2020 .^{52}$ It is important that these efforts remain true to sustainability objectives and are not used as trade barriers to protect domestic agricultural markets. Integrating the results of sustainability audits with analyses of food security impacts of biofuels expansion would provide useful input to policymakers, foundations and private companies investing in biofuels activities, and international agencies seek- 
ing to reduce global poverty and hunger. In defense of the world's poorest populations, it is urgent that the ripple effects of crop-based biofuels on food security and the environmental be understood soon and considered carefully in the design of development policies and investments.

Rosamond L. Naylor is the director of Stanford University's Program on Food Security and the Environment (FSE). Adam J. Liska is a postdoctoral fellow at the Center for Energy Science Research at the University of Nebraska. Marshall B. Burke is a program manager for FSE. Walter P. Falcon is the deputy director of FSE. Joanne C. Gaskell is a Ph.D. candidate at Stanford University. Scott D. Rozelle is a senior fellow at the Freeman-Spogli Institute and FSE at Stanford University. Kenneth G. Cassman is the director of the Center for Energy Science Research at the University of Nebraska The authors thank Andy Melaragno for assistance and Donald Kennedy for a friendly review.

\section{NOTES}

1. The Food and Agricultural Organization (FAO) of the United Nations, The State of Food Insecurity in the World 2006 (Rome: FAO, 2006); and A. V. Banerjee and E. Duflo, "The Economic Lives of the Poor," Journal of Economic Perspectives, Winter 2007: 141-68.

2. The broad definition of sustainable development from the World Commission on Environment and Development (WCED) is: "Humanity's ability to meet the needs of the present without compromising the ability of future generations to meet their own needs." See WCED, Our Common Future (New York: Oxford University Press, 1987), 8.

3. United Nations, UN Millennium Development Goals, see http://www.un.org/millenniumgoals/, (accessed 4 August 2007).

4. FAO, note 1 above; and A. Deaton and V. Kozel, "Data and Dogma: The Great Indian Poverty Debate," The World Bank Research Observer 20, no. 2 (2005): 177-99.

5. This section draws heavily on R. W. Kates, T. M. Parris, and A. A. Leiserowitz, "What Is Sustainable Development?" Environment 47, no. 3 (April 2005): 9-21.

6. About three-quarters of the world's 1.2 trillion barrels of proven oil reserves are located in seven countries: Saudi Arabia, Iran, Iraq, Kuwait, United Arab Emirates, Venezuela, and Russia. Estimates provided by British Petroleum and shown in the Economic and Financia Indicators section of The Economist, 21 June 2007, 106.

7. Engel's Law states that household expenditures on food in the aggregate decline as incomes rise; in other words, the incomes elastiticity of demand for food in the aggregate is less than one and declines toward zero with income growth. See C. P. Timmer, W. P. Falcon, an S. R. Pearson, Food Policy Analysis (Baltimore: Johns Hopkins University Press, 1983), 43.

8. Ibid.; and Banerjee and Duflo, note 1 above.

9. J. Schmidhuber, "Biofuels: An Emerging Threat to Europe's Food Security?" (Paris: Notre-Europe, 2007), http://www.notre-europe.eu/uploads/tx_publication/ Policypaper-Schmidhuber-EN.pdf (accessed 10 July 2007). This paper also shows that if the demand for transportation fuel continues to increase, and crop-based biofuels remain competitive with petroleum-based fuels in terms of energy-content adjusted price, the energy sector can set both a floor price and ceiling price on agricultural commodities used as feedstocks (p. 20-7).
10. A. Elobeid et al., "The Long-Run Impact of CornBased Ethanol on the Grain, Oilseed, and Livestock Sectors: A Preliminary Assessment," Iowa State University Center for Agricultural and Rural Development briefing paper 49, November 2006 (Ames, IA: Iowa State University, 2006); and K. Cassman et al., "Convergence of Agriculture and Energy: Implications for Research and Policy" (Ames, IA: The Council for Agricultural Science and Technology, 2006); and Schmidhuber, note 9 above.

11. For a good qualitative assessment, see C. F Runge and B. Senauer, "How Biofuels Could Starve the Poor," Foreign Affairs, May/June 2007, http://www .foreignaffairs.org/20070501 faessay 86305 -p0/c-fordrunge-benjamin-senauer/how-biofuels-could-starve-thepoor.html. For quantitative estimates, the authors have a grant pending for such a global modeling effort in collaboration with the International Food Policy Research Institute (IFPRI) and the Center for Chinese Agricultural Policy (CCAP). If funded, preliminary results will be available online in late 2008 or 2009 . For more information, contact Rosamond Naylor.

12. FAO, FAOSTAT, http://faostat.fao.org/ (accessed 4 August 2007).

13. Chicago Board of Trade (CBOT), http://www .cbot.com/ (accessed 5 March and 4 August 2007).

14. United States Department of Agriculture, National Agricultural Statistics Service, http://www.nass.usda .gov/ (accessed 29 June 2007)

15. Iowa State University, University Extension, Agricultural Decisionmaker, Table 1, http://www.extension .iastate.edu/agdm (accessed 22 July 2007).

\section{CBOT, note 13 above.}

17. D. Imhoff, Foodfight: A Citizen's Guide to a Food and Farm Bill (Healdsburg, CA: Watershed Media, 2006): 127.

18. United States Department of Agriculture (USDA), "Fact Sheet: A Committment to Rural America," Release No. 0019.07, http://www.usda.gov/wps/portal/!ut/p/ s.7_0_A/7_0_1RD?printable =true \& contentidonly $=$ true \&contentid=2007/01/0019.xml (accessed 12 July 2007).

19. This section draws heavily on research conducted at CCAP. For more information, see J. Huang, H. Qiu, and J. Yang, "Biofuels in China: Trends and Issues," CCAP Working Paper, Institute of Geographical Sciences and Natural Resource Research, Chinese Academy of Sciences, Beijing, China, 2007.

20. United Nations Conference on Trade and Development, "The Emerging Biofuels Market: Regulatory, Trade, and Development Implications" (New York and Geneva: The United Nations, 2006) http://www .unctad.org/en/docs/ditcted20064_en.pdf (accessed 12 June 2007).

21. B. Reddy et al., "Sweet Sorghum-A Potential Alternate Raw Material for Bio-ethanol and Bioenergy," International Sorghum and Millets Newsletter 46 (2005): $79-86$.

22. Reported in The China Daily. See http://www .chinadaily.com.cn/bizchina/2007-07/04/content_ 909803.htm (accessed 10 August 2007).

23. FAO, note 12 above.

24. W. P. Falcon et al., The Cassava Economy of Java (Stanford, CA: Stanford University Press, 1984).

25. FAO, note 12 above. The Dutch have historically been the largest cassava importer for feed, but imports have dropped significantly since 2000 with a change in feed mixture, tariff policy, and environmental policy related to excessive dust in cassava pellet shipments.

26. J. Goldemberg, "Ethanol for a Sustainable Energy Future," Science 315, no. 5813 (9 February 2007) 808-10.

27. "A Special Report on Brazil," The Economist 383, no. 8524 (14 April 2007).

28. E. Smeets et al., Sustainability of Brazilian Bio-ethanol (Utrecht, Netherlands: Copernicus Institute, 2006).
29. Ibid.

30. D. C. Morton et al., "Cropland Expansion Changes Deforestation Dynamics in the Southern Brazilian Amazon," Proceedings of the National Academy of Sciences 103, no. 39 (26 September 2006): 14637-41.

31. B. S. Soares-Filho et al., "Modeling Conservation in the Amazon Basin," Nature 440, no. 7083 (23 March 2006): 520-3.

32. Morton et al., note 30 above.

33. C. A. Klink and R. B. Machado, "Conservation of the Brazilian Cerrado," Conservation Biology 19, no. 3 (2005): 707-13.

34. Morton et al., note 30 above.

35. October contract price, Bursa Malaysia Derivatives Exchange, 17 July 2007.

36. K. H. Aun, "Jatropha Curcas: Agronomic Realities and Commercial Viability," presented at Biodiesel Forum 2007, Jakarta, Indonesia, 28 June 2007.

37. Biopact, Palm Biofuel Survives Low Crude Oil Prices-Official; see http://www.biopact.com (accessed 25 September 2006).

38. The private (market) cost of land is negligible; land costs comprise only 0.15 percent of total production costs, less than the cost of office stationary. Badan Pusat Statistik, Statistik Kelapa Sawit Indonesia (Palm Oil Statistics) 2004 (Jakarta, Indonesia: Badan Pusat Statistik, 2005)

39. B. Goossens et al., "Genetic Signature of Anthropogenic Population Collapse in Orangutans," Public Library of Science Biology 4, no. 2 (February 2006): 285-91.

40. Roundtable on Sustainable Palm Oil (RSPO), History of RSPO, http://www.rspo.org/History_of_RSPO .aspx (accessed 4 August 2007).

41. Badan Pusat Statistik, Pengeluaran Untuk Konsumsi Penduduk Indonesia Per Provinsi (Expenditure for Consumption of Indonesia per Province) 2005, Katalog BPS: 4206 (Jakarta, Indonesia, 2006); and Badan Pusat Statistik, Statistik Indonesia (Statistical Yearbook of Indonesia) 2005/6. Katalog BPS: 1401 (Jakarta, Indonesia, 2007).

42. E. Legowo, First Secretary, National Biofuel Development Committee, in communication with the authors, Jakarta, Indonesia (27 June 2007).

43. P. Conforti, "Price Transmission in Selected Agricultural Markets," Commodity and Trade Policy Research Working Paper No. 7 (Rome: FAO, March 2007).

44. Schmidhuber, note 9 above, 39-43.

45. FAO, note 12 above.

46. FAO, note 12 above.

47. The World Bank, Tanzania Human Resource Development Survey (Dar es Salaam: University of Dar es Salaam and the World Bank), http://www.worldbank .org/LSMS (accessed 1 June 2007).

48. FAO, note 12 above.

49. W. P. Falcon, "Whither Food Aid? A Comment," in P. Timmer, ed., Agriculture and the State (Ithaca, NY: Cornell University Press, 1991): 237-46.

50. Cassman et al., note 10 above; and D. Tilman et al., "Agricultural Sustainability and Intensive Production Practices," Nature 418, no. 6898 (8 August 2002): 671-7.

51. RSPO, note 40 above. The Hawaiian Electric Company is proposing a large investment in a biodiesel plant, which would make it the largest importer of palm oil in the United States. The reviews of this proposal have been overwhelmingly negative, based on sustainability criteria related to RSPO principles.

52. I. Lewandowski and A. P. C. Faaij, "Steps Towards the Development of a Certification System for Sustainable Bio-energy Trade," Biomass Bioenergy 30, no. 2 (February 2006): 83-104. See also the EU standards plan at http://biopact.com/2007/07/highlightsfrom-international.html (accessed 6 July 2007). 